\title{
The Problem of Property Rights to Land Acquisition of State (Jurisprudence and Conditions in Land National Law)
}

\author{
Mahli Ismail \\ Lecturer in Department of Sharia IAIN Lhokseumawe, Indonesia \\ ismailmahli91@gmail.com
}

\begin{abstract}
This study aims to answer the problem of construct and control of the state land by various parties to acquire the property. Structurally scholars of jurisprudence establishof three procedures, such as identification, turn and obtain approval from the government to acquire the property. While the provisions of the National Agrarian Land Legislation of Indonesia set-up of property rights happen in three ways; the determination of the government, the provision of conversion and based on customary law. These requirements include the identification of former state land and wastelands and conditions, cultivation way, and obtaining permission from the government. While distinctive occur in terms designation and use of land in the Treasury Office into the absolute requirement for bookkeeping administrative enforcement of land rights. While the jurisprudence is not required certain types of plants or buildings in the enforcement of land rights administration books. While in general terms there should be plants and buildings as well as the limits of the fence is needed as a requirement in jurisprudence. While at the acreage requirement in the Treasury Office required two hectares per household, is an important requirement for the Treasury Office, because they want to regulate the distribution and people's livelihood of farmers equalization.
\end{abstract} Keywords : property rights; land acquisition; law

\section{Introductions}

Structurally ownership of a plot of land scholars establishes three procedures to obtain ownership of state lands among the identification, exploitation and acquisition of permits from local authorities. Determination procedures and requirements as mentioned above is based on the understanding of scholars from a number of verses and hadith. Many scholars used deductive logic pattern and the pattern Istinbatbayani. While the provisions of the national land legislation have been assigned a variety of rights to land that can be owned by individuals or legal entities. Property rights occurs in three ways ; the determination of the government, the provision of conversion (the Act) and based on customary law.In particular property rights which may be obtained on state land (excluding land property/assets of the country) and of the former abandoned land. The property rights can be obtained after fulfilling a number of procedures and requirements. These requirements include the identification of former state land and wastelands as well as the conditions, the way of cultivating, and obtaining permission from the government.

Kemas Ali (2009) explains that,soil (earth's surface) serves as a provider of nutrients for plants, so the plant achieved production depends on the ability of soil to supply nutrients (soil fertility). Land of human life as a means of structuring and management need to be good and right, making it safe and convenient to own as well as shelter and move. Soil should be constructed so that fulfilled the various necessities of life.IbnKathir (1999) explains that, building a state land so that it can generate, both in farms and in the fishing grounds to be consumed by humans and animals. The man on the ground can be settled, build buildings and move by using the transport from one country to another. Meaning utilize state land given by IbnKathir still relevant to the present life, which turn the soil to meet the various needs and equipped with infrastructure that can support cooperation between the countries in the world, 
in order to meet the needs of each other between nations.IbnKathir opinion is also supported by Razi (1150-1210) explained that, turn on state land means to feed animals and humans. Humans can live with the earth at the same time turn the switch on animals and plants.Because human life and livelihood is dependent upon the energy of water and protein. Where human life requires water, plants vegetable protein) and animal protein) are sufficient certain levels.

The interpretation given by Razi, has a comprehensive meaning, if examined in a variety of disciplines, processing and intensive land development and modern technology, in order to produce maximum crop production and meet the nutritional needs of human life standard (nutritional requirements). For this purpose the necessary range of disciplines, among them; botany, geobotani (the science of plant species) and geonomi (soil science) and nutrients and adequate technology. Muhammad Amin (1836) explains that, in fiqh state land is the land free of a right which is located in a particular area, have not been built by someone, land far from human settlement, not one public and social facilities.

Muhammad Abdullah (1990) clarifies that, abandoned land is land that has been granted the right by the state during the three (3) years of unimproved and unused, back into land controlled by the state and it was decided the legal relationship with the rights holder. So the state land is the land of the free land rights and rights of the former abandoned.Sarakhasi (1986) explains that the concept of state land in fiqh is free soil of a right which is located in a particular area, have not been. Muhammad Abdullah (1990) clarified the abandoned land is land that has been granted the right by the country during the three (3) years not to work and not be used, back into land controlled by the state and determined the legal relationship with the rights holder. Supriyadi (2009) explains that,in the national land law the ground state is land rights and the rights of free land or land owned by the state.[8] While in government regulation (PPRI 2006) explained that, land rights is a state-owned land purchased or obtained at the expense of APBN/APBD or from other legitimate acquisition. Accordingly in the (PPRI 2010) described the right of state-owned land can be evidenced by a certificate. While the concept of wastelands in (PPRI 2010) is a land that has been granted the right by the country for three years was not cultivated, not used, or not used in accordance with the circumstances or the nature and purpose of granting basic rights or mastery. So the state land here is a free land rights, including the former abandoned land.Supriyadi (2009) identified the concept of state landin the national land law, the first free country is the land rights of the Indonesian nation or land controlled by the state. Secondly, the ground state is not free rights of Indonesian nation or land that is not directly controlled by the state. So it is with the state land here is free land rights, including the former abandoned land or land directly controlled by the state to regulate the use, utilization for the welfare of the Indonesian people.

\section{Research Method}

This study use qualitative comparative law.This study methodologically including normative legal research.Soerjono (1986) explains that, legal research primarily a scientific activity that is based on the method, systematic and specific rationale that aims to study one or more symptoms of certain laws by analyzing, examining in depth the legal facts, and then seek a solution to the problems that arise in the relevant symptoms.

Syahrizal (2003) explains that, is a normative legal research study using secondary data as the sole source of data. Law in reality can be researched through studies law in actions. This study gave birth sociological law research. Sociological law research is research on the 
interrelationship between the legal institutions in society. This research is empirical,the data used is primary data. From the definition above shows that, research is a combination of normative legal research with sociological. Therefore, the approach used in this study is the historical approach to jurisprudence, legislation (statute approach), and the sociological approach the people of Aceh. The approach used to trace the history of fiqh opinion of classical and modern scholars to understand texts (the Qur'an and Hadith) as the cornerstone of its legal product according to the climate, time, soil conditions, the technology used and the influence of local culture and the need to ground cover; identifying and building so as to obtain land titles. Legislation historical approach to be studied are the various regulatory legislation, in particular with regard to the procedures, identification, cultivation and utilization as well as how to obtain land titles.

Satjipto Rahardjo(2009) explained that, studied law not only with a legal system, but a cross-cultural investigation by comparing the legal systems of the people with each other. Thus the results can be obtained more thorough understanding about the nature of law. The explanation given by SatjiptoRahardjo has a comprehensive meaning, to understand the law can learn the culture and compared in order to obtain maximum results.MunirFuadi (2005) explains that, comparative law is a knowledge and methods of studying law by reviewing more than one legal system, by reviewing the rules and laws or rules or jurisprudence as well as the opinion of competent experts, to find similarities and differ- differences that can be drawn conclusions and specific concepts, and then sought the causes of differences in historical, sociological,analytical and normative. By using comparative law, it will unanswered the question of why there are differences and similarities between the legal systems being compared. The existence of these differences, because the law is a social phenomenon and is part of the national culture. The difference is caused by the climate, the environment, world view, political patterns and so on. All the above-mentioned approaches used to assess similarities and differences in the legal nature of the identification procedures, utilization, distribution and control of the means to obtain property rights on state land.

\section{Discussion}

\subsection{Acquisition system of State -Owned Land in Fiqh and Treasury Office In jurisprudence}

In jurisprudence, turn on state land is covering work, fence, making roads, building, plant, care for, so it can grow on its own without the help of others. This concept is based on the understanding of scholars interpretation, hadith, fiqh scholars proposals and understanding. Naisaburi (1990) explains that, Opinions about building the right turn state land is a perfect earth by building, planting up perfectly, so that growth can be seen and measured the level of perfection, it can only be called the nature of life. It is understood that, in turn perfect on all types of buildings in form and definitely their life. Allusi (1802-1854) explained that, Turning on state land means to feed animals and humans. Because people can live with the earth at the same time turn the switch on animals and plants .Because human life and livelihood is dependent upon the energy of water and protein. Where human life requires water, plants (vegetable protein) and animal (animal protein) are sufficient certain levels. Abu Bakr (2009) describes a Muslim who occupy a piece of land that has no owner, then he turned to the 
potential tree planting or construct a building or digging wells, then land it becomes his property.

Abu Fatah (1995) identifies that, turn the soil is feeding the animals and humans that much. Turning on earth means to feed animals and humans. Due to turn the earth into his life because animals and humans. Human life is very dependent on the turn earth and animals, as beings in need of a meal. Zarkasyi (1939) explained that, We (God ) turned the ground to perfection, feeding animals and humans that much, turn the earth was turned for animals and humans, because the real animal animate animate human by eating meat and milk. The explanation given by Abu Fatah and the Zarkasyi show cause and effect, turn the earth with a variety of plants and animals as nutrition for humans, without adequate nutrition for human life can not. Due to revive the animals and plants, humans can also be living. The Prophet said, who turned state land for the production of, and what to eat animals, then it becomes alms .(HR. Ahmad).

Who turned off the land tilled by someone before, then it's his right. (HR. Bayhaqi). Imam Hanafi (1986) clarifies that, in figh stipulated requirements and building work on the land the state is working on an ongoing basis, fence and making roads, planting and caring for fruit trees which can be eaten by humans and animals are perfectly grown for three years, irrigate with water (wells or springs and the streams), and build a solid house or cottage. While in government regulation (Act. 10: 2010) explained that, if a person has worked and utilize a piece of land for three years continuously, to the purpose and nature of the rights in the spatial district / city, it will be filed for property rights government. Requirements should be no permit location / open land, and utilization of district/city. But in government regulation (Act.11: 2010) explained that, to be worked for three years continuously in accordance with the distribution of rights.

Ari Sukanti (2008) explains that the acquisition of property rights petition filed with the district land office/Town, The right of people who can be tilled arranged in spatial planning Province and spatial Regional District, bound by the deadline and in accordance designated area of the rights granted to indigenous Indonesian citizens. Having compared the two provisions in the jurisprudence and the Treasury Office of the work and take advantage of state land there are similarities and differences in the requirements. The similarity of the work requirements and utilize the land in earnest for three years and there are plants or buildings and to be occupied.

Why are both of these requirements is important for both of these norms, because both of these requirements the plant or building as a symbol and must be occupied as custody and supervision for rights holders into the main requirement for processing into property rights. While distinctive occur in terms designation and use of land in the Treasury Office into the absolute requirement for bookkeeping administrative enforcement of land rights. While the jurisprudence is not required certain types of plants or buildings in the enforcement of land rights administration books. While in general terms there should be plants and buildings as well as the limits of the fence is needed as a requirement in jurisprudence. But in Jurisprudence focused on the cultivation requirements earnest and produce. While at the acreage requirement in the Treasury Office required two hectares per household, whereas in the jurisprudence of these requirements are not known, but according to the needs of family and companion capital capabilities in building and turn the soil. Whileis this an important requirement for the Treasury Office, because they want to regulate the distribution and people's livelihood of farmers equalization. 
Regarding the land to be cultivated can be customized with Candy Agricultural /KBPN Act. 3 of 1993. The provision of land rights to an individual or a legal entity is done by competent authorities. The authority delegated to the head of the land office District/City to give ownership rights over agricultural land not more than two (2) acres, whereas for nonagricultural land of 2,000 sq $\mathrm{m}$. [28] The category is based on the data (2008) as well as the population density in Aceh are 76 inhabitants per square kilo meter. The area $57.365 .57 \mathrm{~km}$ per side or encompass 12:26\% of the island of Sumatra. Number of District 22, State 5, District 227 and District / Village 5862 the population of 4,664,987 (2009).

The rights set forth in the agrarian law relating to land, the government should realize that by setting these rights to utilize land which they are entitled to good and to perform its obligations towards the ground is good to be helped by the government in this case the Ministry of Agriculture as well as other Ministry as supporters. Because of agrarian land reform in 1960 aiming to hold a fair share of livelihood of the people in the form of land and farmers or apply with the intention that there is a fair distribution of the results, as well as through the overhaul of the structure of the land in order to realize the principle of Social Justice Pancasila. Implement or apply the principle of land for the peasants in order to avoid further instances where the land used as objects or object of speculation and extortion. Reinforce and extend property rights to land for every citizen of Indonesia to these lands of social functioning. Ending the landlord system and eliminate ownership and control of large-scale land (land monopoly) and unlimited, with a minimum threshold setting and determination of land ownership. Increase national production and encourage the convening of intensive agriculture, in order to achieve fair and equitable prosperity coupled with a system of credits that must be addressed to the peasantry. From the above discussion it can be concluded that, the similarity requirements on working and building in earnest for three years and the building and must be occupied. Both requirements are important for both the norm. Since both of those requirements into a requirement which is one of the requirements for processing into property rights.

Differences occur in the requirements of the designation of rights, in fiqh not known plant species or specific buildings in the building and turn on state land. Because it can be adapted to the needs of the family and the market, it can even be used as a commodity export to foreign countries as an industrial raw material. Likewise, building homes is not the size of the land and buildings required, the type of materials used in the building permit. But in National Agrarian Land Legislation of Indonesia is a requirement that is absolutely necessary. Because it is necessary for order and comfort the family and other environments.

\subsection{Obtaining Building Permits in Jurisprudence State Land State Land Rules and Conditions}

Asimin(t.tp) explains that the concept of jurisprudence in the matter of licensing to build two state-owned land. Permit the subject of law (personality) and permit the legal object (ground material). Who and how things can be turned on state land, as well as the need or not to permit the government, it can be argued the following caption: Permit each legal subject is male or female, of understanding and of reason and the power and capably acted before the law. While Hanafi (1985) explained if someone needs (shelter, agricultural land as a sustainer of life).

Hanafi (1985) also describes the work permit conditions and turn on state land, permission is absolutely necessary for state land near the settlement. Syafi i $(150-204 / \mathrm{H})$ clarifying, relative permits necessary for state land far to the settlement and ground potential. 
Hanafi (1998) also describes the work permit conditions and turn on state land, permission is absolutely necessary for state land near the settlement. Syafi i (150-204/H) clarifying, relative permits necessary for state land far to the settlement and ground potential.

Jurists disagreed issue permits and limits of state land to be tilled and turned on, ranged on land close to settlements and land far to the settlement, as well as potential land controlled by the state. The first opinion; look to the public and social facilities, as well as the need for cash income countries (from Kharaj/Land and Building Tax), then who will work on it must obtain permission (strict) of the government to maintain order and benefit of the people. The first opinion; look to the public and social facilities, as well as the need for cash income countries (from Kharaj/Land and Building Tax), then who will work on it must obtain permission (strict) of the government to maintain order and benefit of the people. The second opinion; viewed from the side of state land (idle land) is not used, the soil loosened permit acquisition. The second opinion; viewed from the side of state land (idle land) is not used, the soil loosened permit acquisition.

Ari Sukanti (2008) explains that, working permit and turn state land in the provisions of national land legislation, work on a piece of land in Indonesia previously had to obtain permission from the government district / city or village. In terms of obtaining location permit, permit open and utilization of land, in accordance with the spatial plan Regency/City is equipped with application letter opening the land.[34] Letter of application for the opening of land includes the following requirements: The identity of the applicant; name, villagers, subdistrict, district / municipality. Adult requirements, an Indonesian citizen (citizen), have yet to get / receive permission to open ground. The use of agricultural land.

Once a request is received by the competent authority, check the requirements. If it is full, dealt with a field inspection. Pay attention to the compatibility of land capability, land status, and general spatial planning. Once a request is received by the competent authority, check the requirements. If it is full, dealt with a field inspection. Pay attention to the compatibility of land capability, land status, and general spatial planning. Issuing permission to open the land that contains, among other things. Maximum size of two hectares, a period of three years ,a ban on the transfer, maintain and increase soil fertility, use and benefit, application for land rights (certificate) after three years. To supervise and control the use of open ground permit.Issuing permission to open the land that contains, among other things. Maximum size of two hectares, a period of three years, a ban on the transfer, maintain and increase soil fertility, use and benefit, application for land rights (certificate) after three years. To supervise and control the use of open ground permit. Ari Sukanti (2008) also describes the reporting by the Regent / Mayor implementation of the issuance of license to open the land to the government cq National land agency through the head office of the national land area Provincial agencies.

The procedure for the acquisition of work permits and building on state land above applies throughout Indonesia. Based on Presidential Decree. (Act. 34: 2003) drawn on the national policy in the field of Land. To work the land and build the necessary state government to permit local Regency / City. Pursuant to Law Act. 51: 1960) reported no prohibition control and occupy land without permission or their proxies are entitled.

Having compared the provisions of the acquisition of licenses in the fiqh and the Treasury Office in terms of work, building on state land there are similarities permit legal subject, ie every servant of God who are Muslims,non Muslims, male or female, who understands and puberty as well as power and capably acting in front of the law. Requires 
(shelter, agricultural land as a sustainer of life). Provisions permit work and turn on state land, permits absolutely necessary (strict), for state land near the settlement. Relative necessary permissions (loose), for state land far to the settlement.

Equation government permission based on the provisions in Article 5 of the Law affirms that, agrarian law applies to the earth, water and air space along the customary law is not contrary to the national interests and the state, which is based on the unity of the nation, the Indonesian sociology and with peraturan- rules set out in this Act (LawAct. 5 of 1960) and other regulatory legislation, everything is subject to the elements that rely on religious law. Based on the above, coupled with the majority of the Indonesian population is Muslim, and so are the majority Muslim Aceh, which has been granted privileges in three things, namely privileged in the fields of religion, education, and special in Customs.

Results comparing the two procedures between jurisprudence and the Treasury Office in terms of acquisition work permits, building ground state is as follows: Acquisition of permission to open and work on state land there are similarities: 1. Permission legal subject; every male or female, who understands and puberty as well as power and capable to act in front of the law and was 18 years for men, 17

years for women. Requires (shelter, agricultural land as life support).

2. Provision of working permit and turn on state land there are similarities in the requirements, must use the land for three years can only acquire the property.

a. In jurisprudence and the Treasury Office, permission is absolutely necessary (strict) for state land close to the settlement, and land directly controlled by the state.

b. In jurisprudence, the relative permit is required (loose) for state land far to the settlement, and the ground potential.

c. In jurisprudence and the Treasury Office, working and building permits granted for three years.

While differences occur in terms of area of land, in Law limited to two acres of agricultural land and non-agricultural 2000m while in jurisprudence is not limited according to the needs and inventory of land. Permit the designation and usability in Law very tight, is in relative Jurisprudence / loose. Time working and building permits in fiqh, Law tight for three years.

\section{Conclusion}

The property rights on state land in fiqh can be obtained through a legitimate effort to identify, cultivate and utilize in earnest for three years and received permission from the legitimate government. Property rights on state land in the Treasury Office can be obtained after the soil tilled and exploited for three years in accordance designation rights and the acquisition of licenses and after their application for rights to the government.

The results show the relevance of acquiring permits tight between fiqh, and the Treasury Office in capturing and utilizing state land. Differences occur in the nature and purpose of granting rights and agricultural land for non- farming two acres was 2,000 meters in tight Treasury Office. While the provisions of fiqh very loose terms.

Basic Agrarian Law Act. 5 of 1960 and government regulations Act. 11 Year 2010 which is in line with the jurisprudence on licensing work on state land, working time limits and utilize the land in earnest for a new three year can obtain property rights. If more than three years left uncultivated and no provision was not utilized after the government back into state land or 
land owned by the state. While National Archives of The Republik Indonesia (ANRI) which is not in line with the jurisprudence on the right of establishment and the designation of agricultural land and non-agricultural. BAL Act. 5 of 1960 and government regulations (Abbreviatet PP) Act. 11 Year 2010 which is in line with the jurisprudence on licensing work on state land, working time limits and utilize the land in earnest for a new three year can obtain property rights. If more than three years left uncultivated and no provision was not utilized after the government back into state land or land owned by the state. While KPPN which is not in line with the jurisprudence on the right of establishment and the designation of agricultural land and non-agricultural.

\section{Reference}

Abu Abdillah Muhammad bin 'Umar bin Hasan al-TamimiAl-Razi, Tafsir Al-Razi, (Mawaqi al-Tafasir, 1150-1210. Abu Muhammad Husayin bin Mas`ud Al-Baghawi (w. 516H), Tafsir Al-Baghawi, Dar Thayyibah linnasyar wa Tawzi`,1997.

Abu Al-Fatah Ziya al-Din Nașrullah bin Muhammad bin Muhammad bin `Abd al-Karim alMuwassili, Al-Mathal al-Sa 'ir, Beirut: Maktabah al-`Asriyah, 1995, p. 43

Abu Al-Fida` Ismail bin 'Umar bin Kathir Al-Quraysyi al-Damsyiqi, Tafsir Ibn Kathir, Dar Thayyibah linnasyar wa Tawzi`, 1999.

Abu Bakar Jābir al-Jaza iri, Minhaj al-Muslimin, terj, Andi Subarkah Lc. (Surakarta: Gonilan Kartasura, 2009), p. 675.

Ahmad, Muṣnad Ahmad..., p. 176.

Arie Sukanti Hutagalung, Kewenangan Pemerintah di Bidang Pertanahan, (Jakarta: Raja Grafindo Persada, 2008), p. 168.

Arie Sukanti Hutagalung, Kewenangan Pemerintah di Bidang Pertanahan, (Jakarta: Raja Grafindo Persada, 2008), p. 168.

Arie Sukanti Hutagalung, Kewenangan Pemerintah ..., p. 139.

Athimin, KitabRasa'il li 'Athimin, (Maktabah Syamilah,T.tp.), p. 9.

Badaruddin Muhammad bin Abdullah al-Zarkasyi, al-Burhan fi 'Ulum al-Qur`an, (Maktabah

Syamilah: mawaqi ya`sub, Damsik, 1939), p. 247.

Bayhaqi, Sunan Bayhaqi al-Kubra..., p. 142.

Hanafi, Fiqh Hanafi, Syarh Ma 'ani ..., p. 311.

Hanafi, Fikih Hanafi, Syarh Ma`ani al-Athar...,p. 309-11. Malik, Fikih Malik, Al-Taju wa alIklil Limukhtasar Khalil..., p. 256. Malik, Fikih Malik, Manah al-Jalil Syarh Mukhtasar Khalil..., h. 389. Al-Syafi i, al-Umm ..., p. 42.

http://www.nad.go.id/uploadfiles/PENDUDUK/PENDUDUKBULANJUNI 2008.

Hanafi, Fikih Hanafi, Syarh Ma`ani al-Athar..., p. 311.

Hanafi, Fiqh Hanafi, Bada $i$ al-Sana ${ }^{\prime}$..., p. 55. Hanafi, FiqhHanafi, Tibyan al-Haqa ${ }^{\prime}$..., h. 457.Syamsuddin al-Sarakhasi, Fiqh Hanafi, al-Mabsut ..., p. 10, 410. Hanafi, Fiqh Hanafi;SyarhMa ani al-Athar..., p. 309. See also Malik, Fiqh Malik; Al-Muntaqa Syarh al-Muwatta'..., p. 37.Ibn Qudamah, Al-Syarh al-Kabir..., p. 292. Al-'Athimin, Kitab Rasa'il..., p. 9. Lihatjuga, Ibn Qudamah, Fiqh Hanbali..., p. 384.Hadith Riwayat, AbuDauddanTarmizi, stated the quality of Hadithinihasansahih . See also Al-Șan ani, Subulussalam..., p. 292.

KeppresNomor 34 Tahun 2003 tentang Kebijakan Nasional di bidang Pertanahan. Pasal 2 ayat (1), menyatakan bahwa, sebagian kewenangan Pemerintah di bidang Pertanahan 
dilaksanakan oleh Pemerintah Kabupaten/Kota. Ayat (2), menyatakan bahwa, Kewenangan sebagaimana dimaksud dalam ayat (1) adalah huruf $h$, pemberian izin membuka tanah.

Kemas Ali Hanafiah, Dasar-Dasar Ilmu Tanah, Jakarta: Pt Raja Grafindo Persada, 2009.

Muhammad Amin al-Syakir bin `Abidin, Fiqh Hanafi, Al-Dur al-Mukhtar,(Beirut: Dar al-Fikr, T.tp.), h. 754. Syamsuddin al-Sarakhasi Muhammad bin Ahmad bin Sahil, Fiqh Hanafi, al-Mabsut,( Beirut: al-Qahirah Matba`ah al-Sa`adah, 1986.), h. 10. Al-Kasani, Fiqh Hanafi, Bada $i$ al-Sana $i$ fi Tartibi al-Syara $i$, ( Beirut: Dar Ihya Al-Turath al-`Arabi, 1998), p. 283. See also keterangan dari Malik, Fiqh Malik, al-Muntaqa-Syarh alMuwatta', (Mawaqi Islam,T.tp.), p. 37. Asad ibn al-Furat, Fiqh Malik bin `Amar alAṣbahi al-Mudani, Masriyah, Al-Mudawwanah al-Kubra, ( Beirut: Dar al-Fikr, T.tp.), h. 190. Syafi i, Fiqh Syafi i, Al-Umm, (Mawaqi Islam,T.tp.), p. 42. Ibn Jabarin, Fiqh Hanbali, Syarh Ahsar al-Mukhtashirat li ibn Jabarin, (Mawaqi Islam,T.tp.), p. 1. Syanqiți, Fiqh Hanbali, Syarh Zad al-Mustaqana`li Syanqiți, (Mawaqi`Islām,T.tp.), p. 446.

Muhammad bin Abdillah al-Hakim al-Naysaburi, al-Mustadrak, (Beirut: Dar al-Kitab al‘ilmiyah, 1990), p. 561. Bayhaqi, Sunan Bayhaqi..., p. 148. Ibn Zaijawayh, al-Amwal..., p. 647. Muhammad Al-Șalabi, The Great Leader of 'Umar bin Khattab, terj. Khairul 'Amru Harabah dan Almal Fauzan, (Jakarta: Pustaka Al-Kautsar, 2008), p. 109. See also Muhammad Baltaji, Metodologi Ijtihad 'Umar bin Khattab, terj. Masturi Irhan Lc (Jakarta: Khalifa, 2005), p. 208. Demikian juga dijelaskan Abu Yusuf Ya`kub bin Ibrahim, al-Kharaj, (al-Salafiyat wa Maktabatuha, 1302), p. 37.

Munir Fuadi, Perbandingan Hukum Perdata, (Bandung: Citra Aditya Bakti, 2005), p. 2-3. Al-Naysaburu, Tafsir Al-Naysaburi...,(1990), p.114.

PP.RI. No. 11Tahun 2010, Pasal 1 ayat (3 dan 4). Keppres RI Nomor 34 Tahun 2004 Pasal 2 huruf h menjelaskan tentang perolehan izin dari Pemerintah Kabupaten/Kota terhadap seseorang yang ingin membuka tanah negara.

PP.RI. No. 11 Tahun 2010, Pasal 6 ayat (1) huruf a dan b.

PeraturanMenteriAgraria/KepalaBadanPertanahanNasionalNomor 3 Tahun 1993.

Peraturan Pemerintah Republik Indonesia Nomor 6 Tahun 2006 Tentang Pengelolaan Barang Milik Negara/Daerah, Pasal 2 ayat (1) huruf a dan b.

Peraturan Pemerintah Republik Indonesia Nomor 11 Tahun 2010 Tentang Penertiban dan Pendayagunaan Tanah Terlantar. Bab II Objek Penertiban Tanah Terlantar, Pasal 2 diundangkan di Jakarta pada tanggal 22 Januari 2010. L N. Republik Indonesia Tahun 2010 Nomor 16.

Peraturan Pemerintah Republik Indonesia Nomor 6 Tahun 2006 Tentang Pengelolaan Barang Milik Negara/Daerah, Pasal 2 ayat (1) huruf a dan b.

Satjipto Rahardjo, Hukum dan Perubahan Sosial Suatu Tinjauan Teoritis Serta PengalamanPengalaman di Indonesia, Yogyakarta: Genta Publishing, 2009. Syamsuddin alSarakhasi Muhammad bin Ahmad bin Sahil, Fiqh Hanafi, al-Mabsut, (Beirut: al-Qahirah Matba`ah al-Sa`adah, 1986.), p. 10.

Soerjono Soekanto, Pengantar Penelitian Hukum, (Jakarta: UI Press, 1986), p. 43.

Supriadi, Hukum Agraria, (Jakarta: Sinar Grafika, 2009), p. 21-23.

Supriadi, Hukum Agraria, (Jakarta: Sinar Grafika, 2009), p. 21-23.

Syahrizal, Fakultas Syari ah IAIN Ar-Raniry, ISSN: 1411-2353 Vol.V No. 9, 2003, p. 25. 
Syafì i, Al-Umm..., p. 46-47. Syafìi, Musnad Al-Syafi i..., p. 467. Abū Hasan al-Mawardi, Fiqh Syafi i al-Hawi al-Kabir..., p. 1192. Ibn Hazm, Al-Muhalla ..., p. 126. Lihat juga Ali bin Ahmad bin Hazm, Al-Muhalla Masykul..., p. 456. Bayhaqi, Ma 'rifah Sunan..., p. 176. Kanaz Al-`Amal..., p. 891.

Syamsuddin al-Sarakhasi Muhammad bin Ahmad bin Sahil, Fiqh Hanafi, al-Mabsut, ( Beirut: al-Qahirah Matba`ah al-Sa`adah, 1986.), p. 10.

Syahabuddin Mahmud ibn `Abdillah al-Husayni Al-Allusi, Tafsir Ruhu al-Ma`ani fi Tafsir alQur`an, Mawaqi` al-Tafasir, http//www. Al-Tafasir. Com.T.tp.1802-1854, p. 114

Undang-undang Nomor 51 PRP Tahun 1960 tentang Larangan Pemakaian Tanah Tanpa Izin yang berhak atau kuasanya. L.N. 1960 No. 158. 